\title{
Variability of the Water Quality Characterizing High Andean Lagoons for Tourist Use Evaluated Through Multivariate Statistical Methods, Junín, Peru
}

\author{
María Custodio ${ }^{1 *}$, Gloria Miranda², Richard Peñaloza' , Heidi De la Cruz', \\ Fernán Chanmé
}

1 Universidad Nacional del Centro del Perú, Centro de Investigación en Alta Montaña, Av. Mariscal Castilla Nº3989-4089, Huancayo-Perú.

2 Universidad de Guanajuato, Departamento de Estudios Culturales Demográficos y Políticos, División de Ciencias Sociales y Administrativas, México.

*Corresponding author's e-mail: mcustodio@uncp.edu.pe

\begin{abstract}
The spatial-temporal variability characterizing the water quality of high Andean lagoons for tourist use was evaluated using multivariate statistical methods during 2017 and 2018. The water samples were collected from 14 sampling sites, with three replicates each. The water quality indicators determined were: $\mathrm{pH}$, temperature, $\mathrm{DO}, \mathrm{COD}$, $\mathrm{BOD}_{5}, \mathrm{P}, \mathrm{N}, \mathrm{Fe}, \mathrm{Cu}, \mathrm{Cr}, \mathrm{Cd}, \mathrm{Pb}, \mathrm{Zn}$ and chlorophyll- $a$. The flat cluster analysis (k R cluster) according to Ward's algorithm showed six significantly differentiated groups $(\alpha=0.01)$. In turn, the real similarity profile (SIMPROF) moves markedly away from the obtained low permutation with a large excess of Euclidean similarity with a Pi value of 0.627 . The PCA showed that the first two components recommended by the sedimentation analysis (Scree test) indicated $61.52 \%$ of the total variation of the observations. According to the Spearman range correlation selection criterion, the variables that best interpret the sample distributions are COD, DTS, P, Cd and Zn with a correlation of 0.893 , the DTS being the most important variable with a correlation value of 0.795 . The PERMANOVA analysis according to the flat cluster factor indicated that at least one of the groups is different from the others in relation to the levels of physicochemical characteristics studied. Therefore, all the configured groups are statistically different, demonstrating that each lagoon is different in relation to its physicochemical indicators, according to the season in which it is found.
\end{abstract}

Keywords: water quality, high Andean lagoons, tourist use, indicators, multivariate statistical methods.

\section{INTRODUCTION}

Lagoons are one of the world's most important ecosystems because of the natural heritage they contain. They provide a range of ecosystem goods and services, including habitats for many endemic aquatic species and birds, resting and breeding grounds for a wide variety of migratory birds, scenic landscape beauty, and ecosystem services for the communities directly dependent on these ecosystems [Guswa et al. 2014]. However, these ecosystems become vulnerable to various sources of pollution. The water quality in these ecosystems is determined by various interactions of natural and anthropogenic factors [Lake et al. 2017]. The increase in industrial, fishing, agricultural and recreational activities generate changes in water quality due to cumulative effects, causing great economic and ecological losses [Lee et al. 2018].

In most Latin American countries, the watershed management is inadequate and water pollution is a major concern [Alvarez-Mieles et al. 2013]. The main pollutants identified include heavy metals, which are very harmful due to their toxicity, persistence and possible bioaccumulation and biomagnification in the food chain. In Peru, as in other countries, the aquatic pollution levels 
are increasing rapidly [Eda and Chen 2010; Monroy et al. 2014]. The availability of good quality water is affected by the intensification of anthropogenic activities that undermine the suitability of water for its various uses as well as affect the human well-being and health, biotic integrity, the functioning of ecosystems and their services.

The high Andean lagoons in the Junín region are used mainly for the cultivation of Oncorhynchus mykiss and tourist activity. The Tragadero, Paca and Nahuinpuquio lagoons are used exclusively for tourism. The great flow of tourists that arrive at Tragadero Lagoon comes for bird watching, since this body of water is a reference station for migratory birds. In the three lagoons, the tourist activity has given rise to urban expansion generated by human settlement and industries of different kinds. This exerts strong pressure on the water quality of these ecosystems due to the construction of drains, dumps, silos, animal husbandry and extraction of water for various uses.

The water quality assessment has been implemented by government institutions for some years [MINEN Ministry of the Environment 2017]. To date, conventional methodologies are still being used to monitor the spatial-temporal variations in the physicochemical water quality. The measurement of multiple indicators in different sectors and sampling sites with several repetitions generates a complex data matrix with a large number of physical-chemical indicators, which is often difficult to provide a representative and reliable estimation conclusion. In recent years, suitable methods have been developed for analysing and interpreting this complex data set, such as multivariate methods [Rencher and William 2012]. These methods are widely used in the interpretation of complex data matrices in the assessment of water quality, as they allow both to identify the spatial and temporal patterns of variation in water quality.

In this context and considering that water quality is one of the important factors in human health and ecosystems. It is necessary and important to have reliable information on the threat faced by the water quality of Tragadero, Paca and Nahuinpuquio lagoons in order to direct management strategies and control of water resource contamination. In this sense, the objective of this study was to evaluate the spatial-temporal variability of the water quality of high Andean lagoons for tourist use through multivariate statistical methods, during 2017 and 2018.

\section{MATERIAL AND METHODS}

\section{Description of study area}

The lagoons considered in the study are located in the Mantaro river basin in the Central Andes of Peru, between latitudes: $10^{\circ} 34^{\prime} \mathrm{S}-13^{\circ} 35^{\prime}$ $\mathrm{S}$ and longitudes: $73^{\circ} 55^{\prime} \mathrm{W}-76^{\circ} 40^{\prime} \mathrm{W}$ [Custodio et al. 2018]. Tragadero and Paca lagoons are located in the Jauja province of the Junín region (Figure 1). The Paca Lagoon is located at 3418 meters above sea level, has an extension of $21.40 \mathrm{~km}^{2}$ and a capacity of $85000 \mathrm{~m}^{3}$. Hotels and restaurants were established at the southern end of the lagoon. During the weekends, a large number of tourists arrive to enjoy the scenery and walk through its waters. The Tragadero Lagoon is located at an altitude of 3460 meters above sea level, in the micro watershed of the Yanamarca River. It has a sub-humid climate, with an average temperature of $11.9^{\circ} \mathrm{C}$ and an annual rainfall of $704 \mathrm{~mm}$. The central part of the lagoon is covered by Scirpus californicus and Eichhornia crassipes. The depth of the water is variable and depends on the rainy season and its tributary. It has an average depth of $1.2 \mathrm{~m}$ at most sampling points, except in the central part where the depth is $2.5 \mathrm{~m}$. The Nahuinpuquio lagoon is located in the province of Chupaca at 3430 masl, has a maximum depth of $25 \mathrm{~m}$, extension of $600 \mathrm{~m}$ long by $400 \mathrm{~m}$ wide, with an average temperature of $12^{\circ} \mathrm{C}$.

\section{Selection criteria and location of sampling stations}

The criteria for the location of the sampling stations were defined according to the representativeness of the area in terms of the influence of tourist activity. In the Tragadero and Nahuinpuquio lagoons, four sampling stations were established in each of them and six in Paca Lagoon six. The stations coincide for in situ determination of the physicochemical water indicators and water sampling for indication of nitrates, total phosphorus, $\mathrm{COD}, \mathrm{BOD}_{5}$, heavy metals and chlorophyll- $a$. All stations were georeferenced using a GPS satellite positioner. 


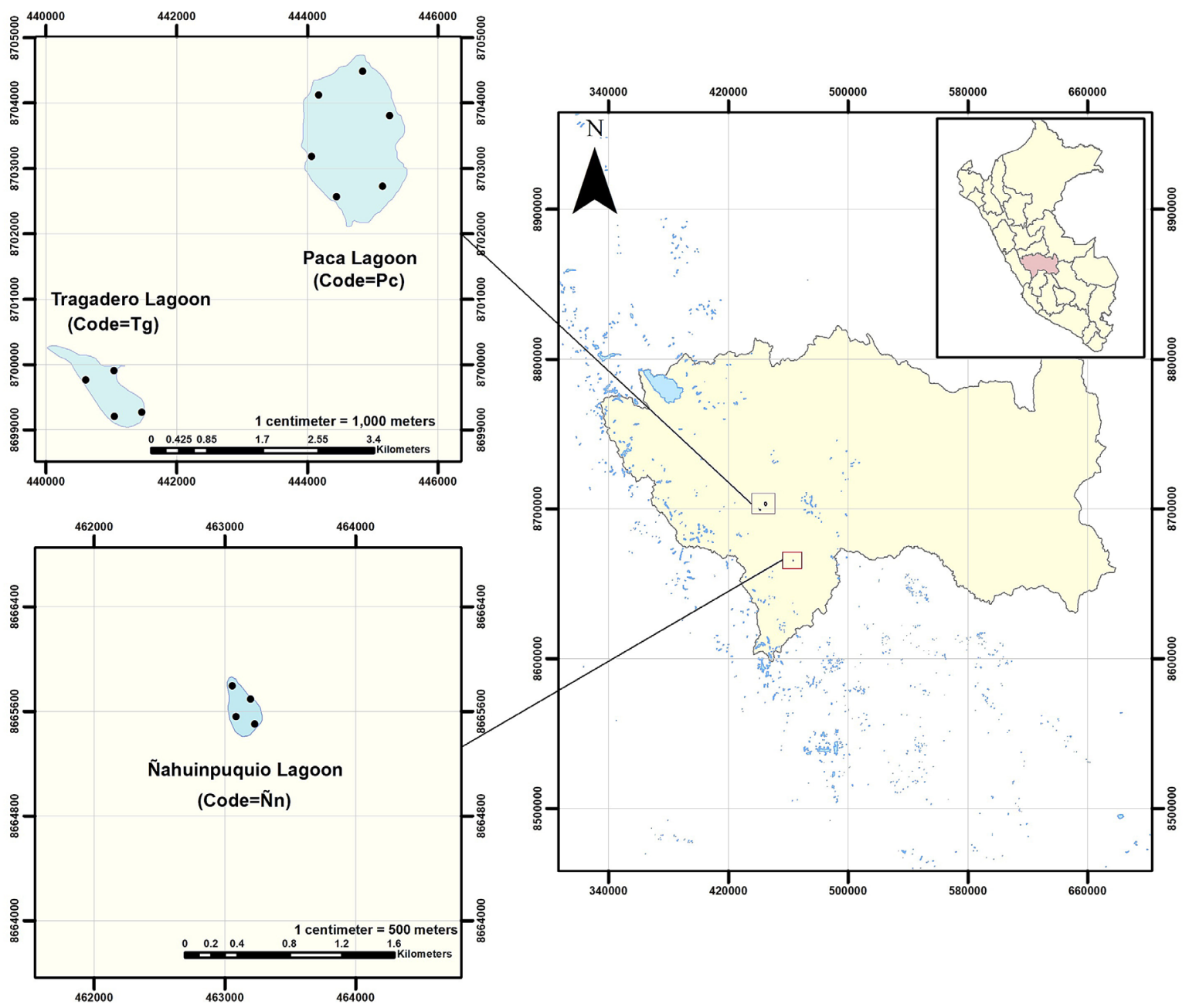

Figure 1. Location of sampling stations in the lagoons evaluated

\section{COLLECTION AND ANALYSIS OF WATER SAMPLES}

\section{Determination of physicochemical indicators in situ and chlorophyll-a}

The water samples were collected at 14 sampling stations, with three repetitions at each, during 2017 and 2018. Dissolved oxygen (DO), dissolved total solids (DTS), electrical conductivity (EC), temperature and $\mathrm{pH}$ were determined in situ using portable Hanna Instruments (HI 991301 Microprocessor $\mathrm{pH} /$ temperature, HI 9835 Microprocessor Conductivity/ TDS and HI 9146 Microprocessor dissolved oxygen). The water samples were also collected at a depth of $20 \mathrm{~cm}$ in twolitre bottles for the determination of nitrates, total phosphorus, chemical oxygen demand (COD), biochemical oxygen demand $\left(\mathrm{BOD}_{5}\right)$ and heavy metals. They were previously treated with a $1: 1$ solution of hydrochloric acid and rinsed with distilled water. The water samples were also collected in amber vials for the determination of chlorophyll- $a$. The preservation and transport of the water samples to the laboratory for analysis were performed according to the standard method [APHA 2012].

The determination of chlorophyll-a was performed with the Aquaprobe AP-5000 multiparametric water quality probe using the 2000/5000-CPHYLL optical electrode. Previously, the sensitivity of the electrode was established with a calibration solution of $500 \mu \mathrm{g} / \mathrm{L}$ of WT Rhodamine, prepared from $200 \mathrm{~g} / \mathrm{L}$ of stock solution using deionized water.

\section{Determining heavy metals}

The preparation of the sample consisted in boiling $250 \mathrm{ml}$ of water to a final volume of 100 $\mathrm{ml}$. Then, $5 \mathrm{ml}$ of ultra-pure hydrochloric acid (supplied by Merck Germany) was added in order 
to achieve complete oxidation and reduce interferences that could be caused by organic matter. The sample was brought to the boil again (until the water was consumed). It was cooled and then $10 \mathrm{ml}$ of distilled water was added, filtered and gauged in a $100 \mathrm{ml}$ pan with $1 \%$ nitric acid [APHA/AWWA/WEF 2012]. The concentration of copper, zinc, iron, lead, cadmium and chromium $(\mathrm{mg} / \mathrm{L})$, was determined with the method of atomic absorption spectrophotometry by flame, according to the methodology recommended by FAO [Custodio et al. 2019], using an AA-6800 Atomic Absorption Spectrophotometer, Shimadzu brand. Previously, the calibration curve was elaborated from the standard solutions for $\mathrm{Pb}, \mathrm{Cu}$, $\mathrm{Fe}, \mathrm{Zn}, \mathrm{Cd}$ and $\mathrm{Cr}$ supplied by Merck with the highest purity level (99.98\%).

\section{Data analysis}

The data were analyzed through Primer V 7 and PAST V 3.0 software. The authors determined the presence of groups with the similarity profile test (SIMPROF), which were tested spatially and temporally [Clarke et al. 2008], verifying the dissection of subgroups by means of hierarchical cluster analysis for non-parametric analysis [Gray et al. 1988]. From the value defined by the number of groups generated a priori, the flat grouping (k-R grouping) was used; which uses a combination of ANOSIM R and similarity analysis (SIMPROF) to determine the optimal value of $\mathrm{k}$ (number of groups) in which the samples should be grouped, all in accordance with the similarity measures of Euclidian distances.

Once the SIMPROF groups were defined and analyzed, the analysis of main components (PCA) of normalized data of the physicochemical parameters of water [Yoon et al. 2016] was carried out to generate perceptual maps. The Scree plot analysis allowed access to the components that explain the greater variability in the data and with it determine the distances of similarity between the groupings by sites. PERMANOVA analysis [Beyer et al. 2011], using unrestricted permutations of normalized data, was performed to test the significant differences given by the SIMPROF analysis. Peer testing was employed to determine which sites given by the SIMPROF cluster were significantly different. Spearman correlation coefficients were tested for each element concentration in the samples by zones and season [Wunderlin et al. 2001], as it is more robust to nonparametric distributions. BEST analysis was used to select the subsets of data in a matrix that best correspond to the multivariate pattern of samples to identify which individual abiotic variables, and which ranges of their values, appear to be responsible for discriminating between different groupings of assemblages.

\section{RESULTS AND DISCUSSION}

Table 1 shows the mean and standard deviation of water quality indicators of tourist lagoons (Paca, Tragadero and Nahuinpuquio) in the Central Andes of Peru, according to the sampling period (2017 and 2018). The mean $\mathrm{pH}$ of the water during this period ranged from 6.78 in the Paca Lagoon to 8.74 in the Tragadero Lagoon, placing it in the $\mathrm{D}$ level range according to the Philippine water quality standard for navigable use [Department of Enviroment and Natural Resources Philippine 2016]. Likewise, the average pH obtained was compared with the guidelines for water intended for human consumption of the World Health Organization [WHO 2011], with the criteria for aquatic life of the Canadian Council of Ministers of the Environment [CCME 2007], and with the environmental quality standards for water of the Ministry of the Environment of Peru [MINEN 2017], the latter two revealing that $\mathrm{pH}$ is in the natural range for life and its various uses. However, they exceeded the range of the WHO guidelines (6.5-8.5). According to this international organization, the $\mathrm{pH}$ has a direct impact on the users of recreational activities; very low or very high values can lead to harmful effects on the skin and eyes [WHO 2003]. It is important to maintain the $\mathrm{pH}$ values above six so that the higher percentage of nitrogen during the denitrification process is not released in the form of nitrous oxide, as this has a negative impact on the quality of the aquatic environment [Custodio et al. 2018]. In addition, no significant differences in $\mathrm{pH}$ values were found between sites and sampling period.

Electrical conductivity (EC) ranged from $215 \mu \mathrm{S} / \mathrm{cm}$ in the Nahuinpuquio lagoon to $295 \mu \mathrm{S} / \mathrm{cm}$ in the Tragadero lagoon; the highest average EC values were recorded during the year 2018. However, these values do not exceed the water quality standards of the MINEN for its various uses; nor do they exceed the values of the Philippine norm for navigable use 
Table 1. Mean and standard deviation of water quality indicators in high Andean lagoons for tourist use during 2017 and 2018

\begin{tabular}{|c|c|c|c|c|c|c|c|c|c|}
\hline \multirow[t]{2}{*}{ Indicator } & \multicolumn{2}{|c|}{ Ñahuinpuquio } & \multicolumn{2}{|c|}{ Paca } & \multicolumn{2}{|c|}{ Tragadero } & \multirow{2}{*}{\begin{tabular}{|c|} 
WQS Peru \\
MINEN
\end{tabular}} & \multicolumn{2}{|c|}{$\begin{array}{l}\text { International } \\
\text { standards }\end{array}$} \\
\hline & 2017 & 2018 & 2017 & 2018 & 2017 & 2018 & & CCME & WHO \\
\hline $\mathrm{pH}$ & $7.75 \pm 0.08$ & $7.97 \pm 0.11$ & $6.78 \pm 0.06$ & $7.94 \pm 0.07$ & $7.53 \pm 0.62$ & $8.74 \pm 0.041$ & $9.0-6.5$ & $9.0-6.5$ & $8.5-6.5$ \\
\hline $\mathrm{EC}(\mu \mathrm{S} / \mathrm{cm})$ & $234.59 \pm 19.40$ & $274.82 \pm 12.94$ & $245.07 \pm 5.36$ & $281.56 \pm 2.42$ & $264.34 \pm 14.43$ & $290.12 \pm 5.01$ & 1000.0 & NA & NA \\
\hline COD (mg/L) & $13.25 \pm 0.51$ & $30.68 \pm 0.73$ & $12.58 \pm 0.43$ & $12.61 \pm 0.34$ & $15.35 \pm 0.15$ & $47.53 \pm 2.56$ & 30 & NA & NA \\
\hline $\mathrm{BOD}_{5}(\mathrm{mg} / \mathrm{L})$ & $3.10 \pm 0.09$ & $8.27 \pm 0.20$ & $3.61 \pm 0.41$ & $3.04 \pm 0.18$ & $12.37 \pm 0.49$ & $12.35 \pm 0.47$ & 5.0 & NA & NA \\
\hline $\mathrm{D} 0$ (mg/L) & $7.11 \pm 0.08$ & $7.09 \pm 0.07$ & $7.19 \pm 0.07$ & $7.05 \pm 0.15$ & $5.80 \pm 0.23$ & $6.12 \pm 0.07$ & $\geq 5.0$ & $5.5-9.5$ & NA \\
\hline Temperature $\left({ }^{\circ} \mathrm{C}\right)$ & $12.26 \pm 0.24$ & $11.36 \pm 0.29$ & $10.66 \pm 0.13$ & $14.61 \pm 0.82$ & $16.64 \pm 0.52$ & $17.26 \pm 0.43$ & $\Delta 3$ & 15 & NA \\
\hline DTS (mg/L) & $2.35 \pm 0.22$ & $2.75 \pm 0.06$ & $2.84 \pm 0.09$ & $3.21 \pm 0.23$ & $8.99 \pm 0.634$ & $5.14 \pm 0.47$ & 1000 & 500 & 600 \\
\hline Total phosphorus (mg/L) & $0.76 \pm 0.00$ & $0.74 \pm 0.00$ & $0.04 \pm 0.00$ & $0.01 \pm 0.0 .00$ & $1.50 \pm 0.00$ & $1.07 \pm 0.00$ & 0.035 & NA & NA \\
\hline Nitrates (mg/L) & $1.48 \pm 0.01$ & $1.55 \pm 0.04$ & $0.37 \pm 0.02$ & $0.09 \pm 0.01$ & $0.81 \pm 0.06$ & $0.47 \pm 0.03$ & 10 & NA & NA \\
\hline Total iron (mg/L) & $0.02 \pm 0.002$ & $1.50 \pm 0.044$ & $0.04 \pm 0.042$ & $0.45 \pm 0.035$ & $0.02 \pm 0.004$ & $0.59 \pm 0.362$ & 5.0 & NA & 0.003 \\
\hline Total copper (mg/L) & $0.03 \pm 0.020$ & $0.04 \pm 0.005$ & $0.06 \pm 0.008$ & $0.05 \pm 0.010$ & $0.04 \pm 0.012$ & $0.04 \pm 0.012$ & 0.1 & 1.00 & NA \\
\hline Total chrome (mg/L) & $0.0001 \pm 0.000$ & $0.0001 \pm 0.000$ & $0.0002 \pm 0.000$ & $0.0001 \pm 0.000$ & $0.0002 \pm 0.000$ & $0.0002 \pm 0.000$ & 0.011 & NA & NA \\
\hline Total cadmium (mg/L) & $0.000 \pm 0.000$ & $0.000 \pm 0.000$ & $0.000 \pm 0.000$ & $0.000 \pm 0.000$ & $0.000 \pm 0.000$ & $0.000 \pm 0.000$ & 0.00025 & NA & NA \\
\hline Total lead (mg/L) & $0.0003 \pm 0.000$ & $0.0002 \pm 0.000$ & $0.0003 \pm 0.000$ & $0.0002 \pm 0.000$ & $0.000 \pm 0.000$ & $0.000 \pm 0.000$ & 0.0025 & 0.01 & 0.003 \\
\hline Total zinc (mg/L) & $0.066 \pm 0.006$ & $0.077 \pm 0.005$ & $0.065 \pm 0.008$ & $0.079 \pm 0.008$ & $0.068 \pm 0.004$ & $0.081 \pm 0.008$ & 0.12 & 5.00 & NA \\
\hline Chlorophyll-a (mg/L) & $0.016 \pm 0.004$ & $0.015 \pm 0.004$ & $0.010 \pm 0.002$ & $0.016 \pm 0.007$ & $0.009 \pm 0.001$ & $0.009 \pm 0.002$ & 0.008 & NA & NA \\
\hline
\end{tabular}

NA: Not applicable.

$(0-1500 \mu \mathrm{S} / \mathrm{cm})$ [Department of Enviroment and Natural Resources Philippine 2016; WHO 2011]. The increase in the average EC values recorded during 2018 is due to the scarce rainfall in the Central Andes of Peru during that year and to the extraction of water carried out by the local population in the periods of absence of rainfall for irrigating the agricultural areas. The decrease in the water level tends to concentrate ions and, as a consequence, increase the EC [Kara et al. 2017]. The DTS values ranged from $2.10 \mathrm{mg} / \mathrm{L}$ in Nahuinpuquio lagoon to $9.40 \mathrm{mg} / \mathrm{L}$ in Tragadero lagoon, with mean values that followed this behavior. However, these results in the three lagoons are low compared to the WHO quality standards [WHO 2006], which indicate that the concentrations below $600 \mathrm{mg} / \mathrm{L}$ are generally considered good for human consumption.

The recorded $\mathrm{BOD}_{5}$ and $\mathrm{COD}$ values showed a range of variation between the sampling sites of the three lagoons. In particular, the Tragadero lagoon recorded the values that exceeded the water quality standards for recreational activities of the MINEN, above all, in the sites near the tributary river, which provides wastewater from the human settlements located along the river. These results reveal organic contamination and are supported by Goher et al. (2014) who refer to urban and industrial wastewater inputs as important sources of organic pollutants. The DO values at all sampling sites in the three lagoons were in the range of Peruvian water quality standards and CCME [CCME 2007] water quality criteria for the suitability of aquatic life. The temperature data recorded in the three lagoons were uniform in most of the evaluated sites, with the exception of the Tragadero lagoon, where a higher temperature was recorded.

The nitrate values recorded in the evaluated lagoons did not exceed the threshold value of the MINEN water quality standards for its various uses, including the recreational use of primary or secondary contact. In contrast, the total phosphorus values recorded during the evaluation period greatly exceeded those standards for its various uses $(0.0035 \mathrm{mg} / \mathrm{L})$, with mean values ranging from 0.04 to $1.50 \mathrm{mg} / \mathrm{L}$. The total phosphorus values recorded during the evaluation period exceeded those standards for its various uses $(0.0035$ $\mathrm{mg} / \mathrm{L}$ ), with the mean values ranging from 0.04 to $1.50 \mathrm{mg} / \mathrm{L}$. The total phosphorus values recorded during the evaluation period exceeded those standards for its various uses $(0.0035 \mathrm{mg} / \mathrm{L})$, with mean values ranging from 0.04 to $1.50 \mathrm{mg} / \mathrm{L}$. These results would be revealing the eutrophication problem that the Tragadero Lagoon is experiencing. The average values of Chlorophyll- $a$ recorded in the three lagoons exceeded the national 
quality standard $(0.008 \mathrm{mg} / \mathrm{L})$. The values for iron, copper, chromium, cadmium, lead and zinc did not exceed the threshold value of the MINEN water quality standards for recreational use, nor the WHO guidelines for human consumption, except for the recorded iron values.

The Spearman correlation analysis in Table 2 shows the levels of significantly high positive correlation between variables. The EC has a positive correlation with the variables $\mathrm{pH}, \mathrm{COD}, \mathrm{BOD}_{5}$, temperature, DTS, Fe, $\mathrm{Cd}$ and $\mathrm{Zn}$. The affinity of EC with DTS would be due to the decomposition and mineralization of organic materials, which would be increasing conductivity levels [Venkatesharaju 2010]. The indicator that has the greatest number of correlations with the other indicators is $\mathrm{DO}$, which correlates negatively with $\mathrm{EC}, \mathrm{COD}$, $\mathrm{BOD}_{5}$, temperature, DTS, $\mathrm{P}, \mathrm{Cd}$ and $\mathrm{Pb}$. The effect of the $\mathrm{DO}$ and $\mathrm{pH}$ reduction would explain the chemical transformations of some metals that would modify the distribution of trace metals in several chemical fractions [Khalid 1978], some of them salts, increasing the values of EC.

Figure 2 shows the grouping given by the flat cluster analysis ( $\mathrm{k}$ R cluster) for the sampling stations in the tourist lagoons grouped according to Ward's algorithm. This decisive grouping dendrogram is based on the physicochemical indicators of water quality and Euclidean distances. The dendrogram shows six significantly differentiated groups $(\alpha=0.01)$ that coincide with the interaction of the sampling station and season factors. In other words, the six groups formed by the analysis agree with what is preset at the time and space level. The average distance of the values in relation to their centroid was 78.95; which is too high to define the groups, since they are chosen to minimize the sum of the average ranges of samples for the other members of their group [Clarke 2008].

Figure 3 shows that the real similarity profile (SIMPROF) moves markedly away from the low permutation obtained with a large excess of high and very low Euclidean similarities with a Pi value of 0.627 and at a significance level of 0.01 . This result reveals that there are highly differentiated groups at a multivariate level. The importance of the SIMPROF analysis and flat cluster application enabled to identify the behavior of the data, as well as organize and select the groups of interest for a better analysis. The results reveal that the Tragadero lagoon for both seasons presents two highly differentiated groups at a Euclidean distance of cut 15 . In order to determine the characteristics of the indicators in study that define the difference of these groups, we proceeded with the principal components analysis (PCA).

The principal components analysis showed that the first two components recommended by the sedimentation analysis (Scree test) indicated $61.52 \%$ of the total variation of the observations, presenting the first component with a value of $41.85 \%$ (Figure 4 ).

Table 2. Correlation of Spearman between water quality indicators of lagoons of tourist use in the central region of Peru

\begin{tabular}{|c|c|c|c|c|c|c|c|c|c|c|c|c|c|c|c|c|}
\hline Indicator & $\mathrm{pH}$ & $\mathrm{EC}$ & $\mathrm{COD}$ & $\mathrm{BOD}_{5}$ & $\mathrm{DO}$ & $\mathrm{T}^{\circ}$ & $\mathrm{DTS}$ & $\mathrm{P}$ & $\mathrm{N}$ & $\mathrm{Fe}$ & $\mathrm{Cu}$ & $\mathrm{Cr}$ & $\mathrm{Cd}$ & $\mathrm{Pb}$ & $\mathrm{Zn}$ & Chlorophyll-a \\
\hline $\mathrm{pH}$ & & $3 \mathrm{E}-05$ & 0.003 & 0.122 & 0.057 & 0.001 & 0.108 & 0.495 & 0.809 & $3 \mathrm{E}-05$ & 0.199 & 0.884 & 0.114 & 0.605 & 0.005 & 0.957 \\
\hline $\mathrm{EC}$ & 0.705 & & 0.013 & 0.022 & 0.015 & 0.000 & 0.001 & 0.670 & 0.487 & 0.002 & 0.150 & 0.332 & 0.016 & 0.468 & 0.008 & 0.653 \\
\hline $\mathrm{COD}$ & 0.546 & 0.465 & & 0.000 & 0.013 & 0.013 & 0.227 & 0.000 & 0.000 & 0.068 & 0.014 & 0.399 & 0.030 & 0.405 & 0.432 & 0.266 \\
\hline $\mathrm{BOD}_{5}$ & 0.299 & 0.431 & 0.743 & & 0.005 & 0.025 & 0.003 & 0.000 & 0.045 & 0.784 & 0.131 & 0.175 & 0.007 & 0.220 & 0.803 & 0.011 \\
\hline $\mathrm{DO}$ & -0.363 & -0.457 & -0.462 & -0.512 & & 0.000 & 0.000 & 0.000 & 0.355 & 0.977 & 0.079 & 0.145 & 0.000 & 0.033 & 0.288 & 0.054 \\
\hline Temperature & 0.574 & 0.659 & 0.466 & 0.422 & -0.799 & & 0.000 & 0.009 & 0.865 & 0.849 & 0.024 & 0.141 & 0.000 & 0.188 & 0.126 & 0.159 \\
\hline $\mathrm{DTS}$ & 0.310 & 0.577 & 0.236 & 0.547 & -0.651 & 0.744 & & 0.122 & 0.071 & 0.796 & 0.690 & 0.018 & 0.000 & 0.129 & 0.381 & 0.023 \\
\hline $\mathrm{P}$ & 0.134 & 0.084 & 0.702 & 0.720 & -0.616 & 0.484 & 0.299 & & 0.000 & 0.180 & 0.004 & 0.091 & 0.001 & 0.018 & 0.380 & 0.031 \\
\hline $\mathrm{N}$ & 0.048 & -0.137 & 0.643 & 0.382 & -0.182 & -0.034 & -0.346 & 0.644 & & 0.752 & 0.043 & 0.612 & 0.852 & 0.777 & 0.475 & 0.999 \\
\hline $\mathrm{Fe}$ & 0.700 & 0.555 & 0.350 & 0.054 & 0.006 & 0.038 & -0.051 & -0.261 & 0.063 & & 0.926 & 0.130 & 0.576 & 0.426 & 0.003 & 0.333 \\
\hline $\mathrm{Cu}$ & -0.250 & -0.279 & -0.458 & -0.293 & 0.338 & -0.427 & -0.079 & -0.523 & -0.385 & 0.018 & & 0.185 & 0.236 & 0.586 & 0.634 & 0.345 \\
\hline $\mathrm{Cr}$ & -0.029 & 0.190 & 0.166 & 0.264 & -0.283 & 0.285 & 0.442 & 0.326 & -0.100 & -0.293 & -0.258 & & 0.009 & 0.790 & 0.457 & 0.120 \\
\hline $\mathrm{Cd}$ & 0.305 & 0.451 & 0.412 & 0.499 & -0.674 & 0.731 & 0.687 & 0.579 & 0.037 & -0.110 & -0.232 & 0.485 & & 0.145 & 0.907 & 0.004 \\
\hline $\mathrm{Pb}$ & 0.102 & -0.143 & 0.164 & 0.239 & -0.403 & 0.256 & 0.294 & 0.443 & 0.056 & -0.157 & 0.108 & 0.053 & 0.282 & & 0.771 & 0.863 \\
\hline $\mathrm{Zn}$ & 0.517 & 0.490 & 0.155 & -0.049 & -0.208 & 0.296 & 0.172 & -0.172 & -0.141 & 0.535 & 0.094 & -0.147 & -0.023 & 0.058 & & 0.527 \\
\hline $\mathrm{Chlorophyll}$ & -0.011 & -0.089 & -0.217 & -0.474 & 0.369 & -0.274 & -0.427 & -0.409 & 0.000 & 0.190 & 0.185 & -0.300 & -0.531 & -0.034 & 0.125 & \\
\hline
\end{tabular}

Significant correlation $(\mathrm{p}<0.05)$. 


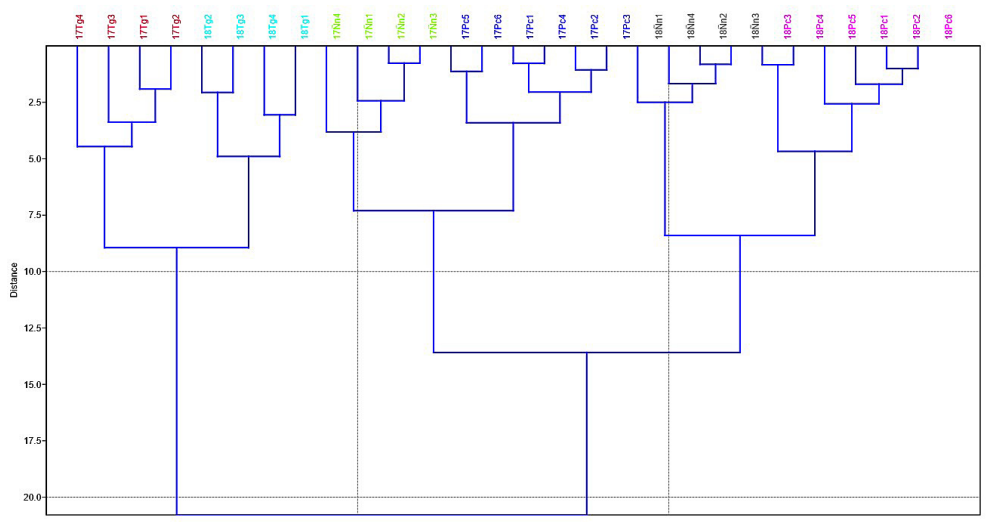

Figure 2. Cluster analysis of tourist use lagoon sampling stations according to Ward's algorithm, differentiated by flat clustering ( $\mathrm{k}$ R cluster)

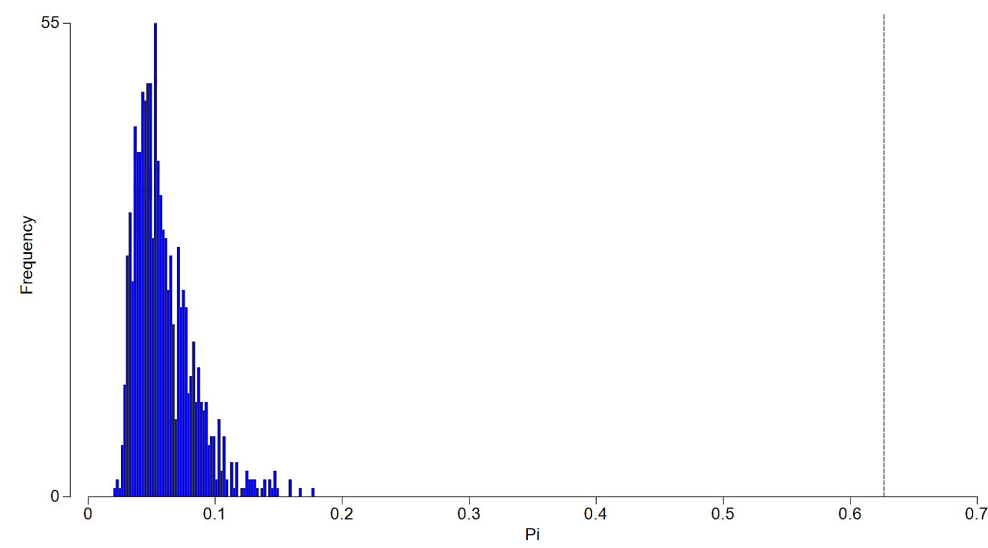

Figure 3. Similarity profile frequency (SIMPROF) for significant structure tests testing the predefined grouping (gaps)

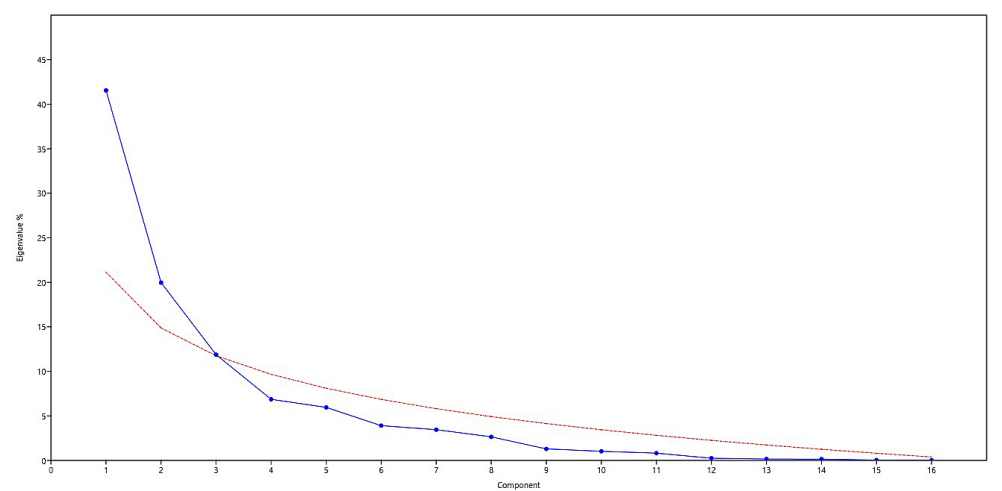

Figure 4. Sedimentation analysis for selection of principal components according to the eigenvalue size

Flat clustering shows the groups predefined by spatial-temporal factors and reveals that these groups are significantly different from each other. These were labeled as follows: the Tragadero lagoon (Tg) for 2017 with label B and for 2018 with label $\mathbf{C}$, both differentiated at a value of 5.5
Euclidean distance as shown in Figure 5. The lagoons of Paca (Pc) and Nauhinpuquio (Ñn) for the year 2017 have the label $\mathbf{D}$ and $\mathbf{F}$, respectively. These groups differ significantly from their counterparts for the 2018 season, labeled with $\mathbf{A}$ and $\mathbf{E}$. 
The first two components indicate a good interpretation of the perceptual map in relation to the original values, and that the distributions of the data conform to particular physicochemical indicators. The PC 1 with a variation percentage of $41.55 \%$ shows that there is a marked difference between two groups; those of the Tragadero lagoon and those of the other two lagoons. The directions of the vectors of the indicators under study indicate that this lagoon differs from the others because it has contrasts with the rest of the lagoons. It is observed that the highest positive charges for $\mathrm{PC} 1$ are given by $\mathrm{BOD}_{5}(0.347)$, Cd (0.344), temperature (0.324), DTS (0.334), P $(0.325)$ and the highest negative charges are given by DO (-0.36). This analysis indicates that the distributions of the observations are given in special degree by these indicators; that is to say that high values are found in the Tragadero lagoon in relation to the other lagoons for BOD5 (Table 1). Together, PC1 indicates that the Tragadero lagoon for both seasons has very low DO values, in relation to the others.

The second major component shows strong negative charges for the vectors of the indicators $\mathrm{pH}(-0.356)$, EC (-0.388), Fe (-0.50) and $\mathrm{Zn}$ $(-0.42)$. This result would explain the distribution of the groups for component 2, separated at a distance of about 5.5, generating 4 differentiated groups for these two components. The effect of temporal and spatial factors on the assessed gaps is evident. It was observed that groups B and C of the Tragadero Lagoon are different from the other groups and reveal a greater concentration of heavy metals with a tendency to increase with time, showing that the anthropogenic pressure exerted on the lagoons is gradual and increases from one year to the next. Since the distance is highly significant, it can be inferred that pollution is very high for each tourist season that this lagoon supports, in relation to the Paca and Nahuinpuquio lagoons. It is observed that for component 1, the difference is short but significant, separating around 2.8 according to the Euclidean distance, adjusting with the flat cluster analysis. The observations of the Paca lagoon for 2017 have the label D and the Nahuinpuquio lagoon for the same year has the label $\mathbf{F}$ (Figure 5). The separation of their pairs for 2018 maintains significant difference but increases their values for the vectors of the physicochemical indicators, assimilating to the effect of the time for the Tragadero lagoon, revalidating the assumption that the tourist activity in the evaluated lagoons tends to follow a similar behavior, possibly to the number of people who visit them, the amount of waste thrown or other factors outside the tourist context such as the agricultural activity and the tributary of sanitary mouths.

The Best analysis shows a better profile analysis of the distribution of the samples in relation to the vectors. According to the Spearman's range correlation selection criterion, it was found that the indicators that best interpret the sample distributions are COD, DTS, $\mathrm{P}, \mathrm{Cd}$ and $\mathrm{Zn}$ with a correlation of 0.893 ; DTS is the most important indicator of water quality deterioration for general recreational use [Cude, 2001], with a correlation value of 0.795 . In analogy to these results,

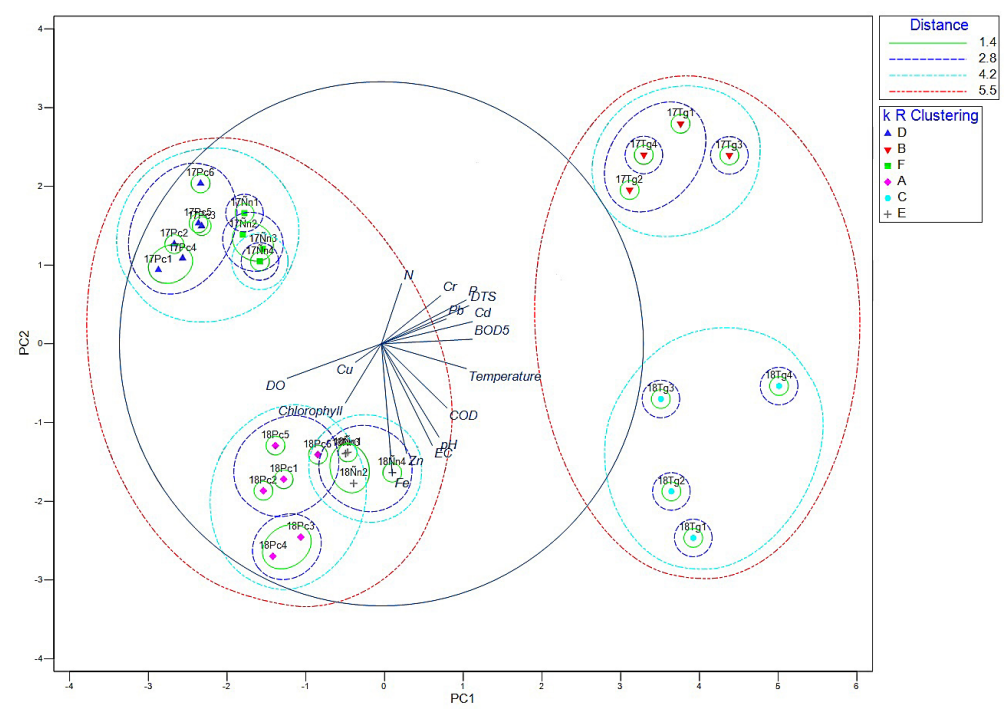

Figure 5. Perceptual map of principal components analysis based on the physical - standardized chemical indicators of lagoons of tourist use according to SIMPROF 
the PCA referring to these main indicators was blocked (Figure 6), finding that the disintegration of the observations in PC1 is influenced by $\mathrm{P}$, DTS and Cd, being the Tragadero lagoon (groups $\mathbf{B}$ and $\mathbf{C}$ ) the one with the highest concentration levels of these indicators. These results coincide with the greater anthropogenic pressure that this lagoon supports, such as tourism, agricultural activity, cattle ranching and urban activities in general.

The Permutational Multivariate Analysis of Variance (PERMANOVA) analysis according to the flat cluster factor shows a statistical significance $(\mathrm{a}=0.05)$, indicating that at least one of the groups is different from the others, in relation to the physicochemical indicators studied. Table 3 shows that all the groups given by the flat cluster analysis are significantly different and each gap is different in relation to their physicochemical indicators indistinctly in the year in which they are found.

\section{CONCLUSIONS}

In this study it was corroborated that the previously defined spatiotemporal grouping shows significant differences at a multivariate study level. This is adjacent to the flat cluster analysis, which groups the observations in the same way, indicating that the effect of the interaction of spatiotemporal factors significantly influences the physicochemical quality of the water in the lagoons exposed to tourist activity.

Multivariate analysis revealed that tourism contributes to the increase in concentrations of DTS, phosphates and some heavy metals such as cadmium. These three indicators significantly explain the spatial differences of the gaps under study. The PCA showed that the importance of physicochemical indicators changes from one assessment period to another and that the indicators that most contribute to the variation in water quality in a given period might contribute less or not at all in another period. For the temporal differences, visible in $\mathrm{PC} 2$, it was observed that the

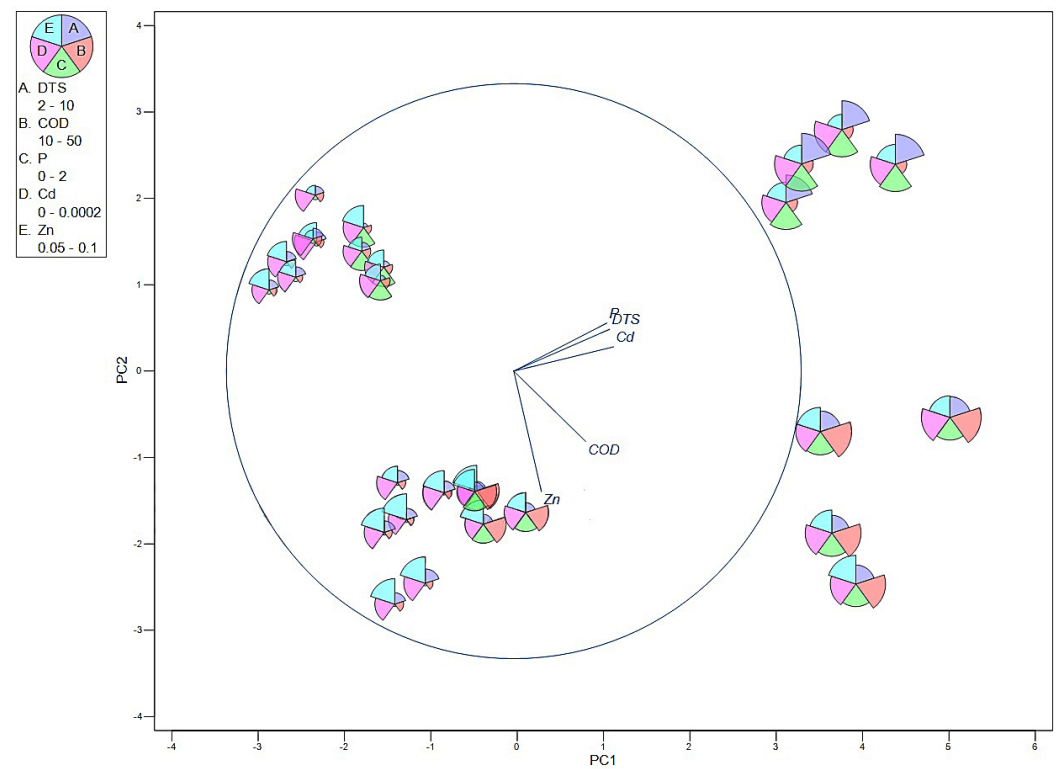

Figure 6. Perceptual map of principal components analysis based on the physicochemical indicators of water quality that best represent the distribution

Table 3. PERMONVA analysis of two pairs of water quality indicators

\begin{tabular}{|c|c|c|c|c|c|c|}
\hline Indicator & Pc2017 & Tg2017 & Ñn2017 & Pc2018 & Tg2018 & Nn2018 \\
\hline Pc2017 & & & & & & \\
\hline Tg2017 & 0.0045 & & & & & \\
\hline Ñn2017 & 0.0047 & 0.0275 & & & & \\
\hline Pc2018 & 0.0031 & 0.0052 & 0.0043 & & & \\
\hline Tg2018 & 0.0056 & 0.0333 & 0.0300 & 0.0046 & & \\
\hline Ñn2018 & 0.0060 & 0.0264 & 0.0297 & 0.0054 & 0.0284 & \\
\hline
\end{tabular}


COD level and $\mathrm{Zn}$ concentrations define the differences between the groups.

The results show that the different anthropogenic activities carried out around the lagoons must be taken into account, since they significantly influence the physicochemical quality. In addition, they reveal that the use of multivariate statistical analysis methods is suitable for interpreting complex water quality data sets and understanding the changes related to time and space. Therefore, these results will contribute to alerting the authorities, initiating the recovery procedures for the Tragadero Lagoon, given the negative results, and replicate the care taken in groups D and F of the Nahuinpuquio Lagoon, whose indices are low in relation to the other lagoons, but whose anthropogenic activity is similar to that of groups $\mathrm{B}$ and $\mathrm{C}$.

\section{Acknowledgements}

The authors express their gratitude to the General Research Institute of the Universidad Nacional del Centro del Peru for the financing of the study, to the Water Research Laboratory for allowing us to make use of the equipment and materials for this study.

\section{REFERENCES}

1. Alvarez-mieles, G., Irvine, K., Griensven, A. V, \& Arias-hidalgo, M. (2013). Relationships between aquatic biotic communities and water quality in a tropical river - wetland system (Ecuador). Environmental Science and Policy, 34, 115-127. https:// doi.org/10.1016/j.envsci.2013.01.011

2. APHA/AWWA/WEF. (2012). Standard Methods for Examination of Water and Wastewater (Standard Methods for the Examination of Water and Wastewater). In American Public Health Association (APHA): Washington, DC, USA.

3. Beyer, S., Kinnear, A., Hutley, L. B., McGuinness, K., \& Gibb, K. (2011). Assessing the relationship between fire and grazing on soil characteristics and mite communities in a semi-arid savanna of northern Australia. Pedobiologia, 54(3), 195-200. https://doi.org/10.1016/j.pedobi.2011.03.002

4. CCME (Canadian Council of Ministers of the Environment). (2007). For the protection of aquatic life 2007. In W. Canadian Council of Ministers of the Environment, 1999 (Ed.), Canadian environmental quality guidelines, 1999 (Vol. 67, pp. 14-21).

5. Clarke, K. R., Somer, P. J., \& Gorley, R. N. (2008).
Journal of Experimental Marine Biology and Ecology Testing of null hypotheses in exploratory community analyses : similarity pro fi les and biota-environment linkage, 366, 56-69. https://doi. org/10.1016/j.jembe.2008.07.009

6. Clarke, K. R., Somerfield, P. J., \& Gorley, R. N. (2008). Testing of null hypotheses in exploratory community analyses: similarity profiles and biotaenvironment linkage. Journal of Experimental Marine Biology and Ecology. https://doi.org/10.1016/j. jembe.2008.07.009

7. Cude, C. G. (2001). Oregon water quality index a tool for evaluating water quality management effectiveness. Journal Of The American Water Resources Association, 37(1), 125-137. https://doi. org/10.1111/j.1752-1688.2001.tb05480.x

8. Custodio, M., Peñaloza, R., Chanamé, F., Yaranga, R., \& Pantoja, R. (2018). Assessment of the Aquatic Environment Quality of High Andean Lagoons using Multivariate Statistical Methods in Two Contrasting Climatic Periods. Journal of Ecological Engineering, 19(6), 24-33. https://doi. org/10.12911/22998993/92677

9. Custodio, M., Zapata, F. C. C., Flores, D. J. C., \& Gutiérrez, W. B. (2019). Potentially toxic metals in lotic systems with aptitude for aquaculture at the watershed Mantaro River, Peru. Ambiente e Agua - An Interdisciplinary Journal of Applied Science, 14(114). https://doi.org/10.4136/1980-993X

10. Department of Enviroment and Natural Resources Philippine. (2016). Water Quality Guidelines and General Effluent Standars. Phillippine.

11. Eda, L. E. H., \& Chen, W. (2010). Integrated water resources management in Peru. In Procedia Environmental Sciences (Vol. 2, pp. 340-348). https:// doi.org/10.1016/j.proenv.2010.10.039

12. Goher, M. E., Hassan, A. M., Abdel-moniem, I. A., Fahmy, A. H., \& El-sayed, S. M. (2014). Evaluation of surface water quality and heavy metal indices of Ismailia Canal, Nile River, Egypt. The Egyptian Journal of Aquatic Research, 40(3), 225-233. https://doi.org/10.1016/j.ejar.2014.09.001

13. Gray, J., Aschan, M., Carr, M., Clarke, K., Green, R., Pearson, T., ... Warwick, R. (1988). Analysis of community attributes of the benthic macrofauna of Frierfjord/Langesundfjord and in a mesocosm experiment. Marine Ecology Progress Series, 46(June), 151-165. https://doi.org/10.3354/meps046151

14. Guswa, A. J., Brauman, K. A., Brown, C., Hamel, P., Keeler, B. L., \& Sayre, S. S. (2014). Ecosystem services: Challenges and opportunities for hydrologic modeling to support decision making. Water Resources Research, 50(5), 4535-4544. https://doi. org/10.1002/2014WR015497

15. Kara, G. T., Kara, M., Bayram, A., \& Gündüz, O. (2017). Assessment of seasonal and spatial varia- 
tions of physicochemical parameters and trace elements along a heavily polluted effluent-dominated stream. Environ Monit Assess, 189(11), 1-16. https://doi.org/10.1007/s10661-017-6309-4

16. Khalid, R. A., Patrick, W. H., \& Gambrels, R. P. (1978). Effect of Dissolved Oxygen on Chemical Transformations of Heavy Metals, Phosphorus , and Nitrogen in an Estuarine Sediment", 35, 21-35.

17. Lake, T., Belal, A. A. M., El-sawy, M. A., \& Dar, M. A. (2017). The effect of water quality on the distribution of macro-benthic fauna in Western Lagoon. The Egyptian Journal of Aquatic Research, 42(4), 437-448. https://doi.org/10.1016/j. ejar.2016.12.003

18. Lee, S. J., Lee, E. H., \& An, K. G. (2018). Lotic ecosystem health assessments using an integrated analytical approach of physical habitat, chemical water quality, and fish multi-metric health metrics. Polish Journal of Environmental Studies, 27(5), 2113-2131. https://doi.org/10.15244/pjoes/78044

19. MINEN Ministry of the Environment. (2017). DS N ${ }^{\circ}$ 004-2017-MINEN, Environmental Quality Standards for Water (EQS-Water). El Peruano, 10-19.

20. Monroy, M., Maceda-Veiga, A., \& de Sostoa, A. (2014). Metal concentration in water, sediment and four fish species from Lake Titicaca reveals a large-scale environmental concern. Science of the Total Environment, 487(1), 233-244. https://doi. org/10.1016/j.scitotenv.2014.03.134

21. Rencher, A. C., \& William, F. C. (2012). Methods of multivariate analysis: Third edition. Methods of Multivariate Analysis: Third Edition. https://doi. org/10.1002/9781118391686

22. Venkatesharaju, K. (2010). Physico-chemical and bacteriological investigation on the river Cauvery of kollegal stretch in, 6(I), 50-59.

23. WHO. (2003). Guidelines for safe recreational water environments, 1.

24. WHO. (2006). Guidelines for Drinking-water Quality (Vol. 1).

25. Wunderlin, D., Diaz, M., Amé, M., Pesce, S., Hued, A., \& Bistoni, M. (2001). Pattern recognition techniques for the evaluation of spatial and temporal variations in water quality. A case study: Suquia river basin (Cordoba - Argentina ), 35(12), 28812894.

26. Yoon, J., Bhatta, K., Rastogi, G., Muduli, P. R., Do, Y., Kim, D., Ajit, K., Joo, G. (2016). Application of multivariate analysis to determine spatial and temporal changes in water quality after new channel construction in the Chilika Lagoon. Ecological Engineering, 90, 314-319. https://doi.org/10.1016/j. ecoleng.2016.01.053 